\title{
THE RELEVANCE OF THE CHURCH IN OPPRESSIVE SITUATIONS: THE PRAXIS OF LIBERATION THEOLOGY IN AFRICA
}

\author{
Kanayo Louis Nwadialor* \\ \& \\ Charles Chukwuemeka Nweke* \\ http://dx.doi.org/10.4314/og.v10i 1.5
}

\begin{abstract}
In many respects, the situation in Africa now resembles the situation in Latin America under which liberation theology irrupted. A situation under which both human and non human factors (external and internal) reduces the masses of the people to abject poverty and misery. African theologians have been attempting to grapple with these problems and to relate the gospel to the practical issues, whether social and political, cultural and liturgical which confronts them. This is because the Christian faith is not something extrinsic to the afflictions of the oppressed, but it is rather a motivating force which demands that the oppressed must be liberated in order to make room for the realization of the historical translation of the salvific deed of Jesus and the salvific will of God. However, so far, it appears that African theologians have not given enough thought to linking theology closely to the socio-economic and political situations in Africa as it has been done in Latin America. This situation has therefore called for an adequate and clear theology and the development of liberation praxis born out of the living experience of the African people. We therefore believe that the stage is now set when African theologians will help the people to uncover the liberative dimension of their faith and call for a discipleship in praxis as the beginning of theological reflection.
\end{abstract}

\section{Introduction}

For the African peoples, and indeed the developing nations generally, one of the foremost aspirations is freedom or liberation. The term in its simplest meaning connotes the salvation of both the soul and the body, a quest for incarnated Christianity. This freedom 
Ogirisi: a new Journal of African Studies vol 102013 whether personal or collective is being more and more looked upon, in recent times since injustice and other evils are incarnated in African socio-political structures. Since independence, to say the least, the language of the black African has been that of liberation and indigenization of Christianity in the local culture. Hence Appiah-Kubi (1997) observes that there is more than ample evidence to show that the main preoccupation of many African Christians is redemption from physical dilemmas or evil forces. The idea of deliverance is the commonest theme in the hymns, prayers, and catechisms of the indigenous African churches. This idea ties in with the traditional African concept of religion and therefore God and Christ.

Since independence, what has characterized the African in his concrete and historical setting is his continuous struggle for liberation directed against one or the other Africa's major sociopolitical ills. At times the liberation struggle has taken on the character of political decolonization. At other times, freedom from economic dependence; at other times too, structural violence, oppression, hunger, disease, unemployment, and so on. However, the struggle has not solely been a yearning for liberation from want, disease, racism, violence, oppression. The African has also been out for self-assertion, self-projection, integral development, active participation in history, full mastery and control of his affairs, and so on. According to Okolo (1985),

The African wants to reassert himself as the master and main controller of his world. Consequently the struggle to eliminate those conditions which oppress him and make him slavishly subjected to others in his economic, social, political and religious life continues. This is why freedom is a prime value for him as well as the theme of his everyday language. (p. 91).

African theologians are attempting to grapple with these problems and to relate the gospel to the practical issues, whether social and 
Nwadialor \& Nweke: The Relevance of the Church in Oppressive Situations...

political, or cultural and liturgical which confront them. Hence, Barrett (1970) notes that,

The modern world is prepared to treat human relationships with a greater seriousness than any generation before it, and that therefore this second reformation must start from human experience and relationships. But at this point, it is Africa that is the teacher of Europe. (p. 170).

However, naturally, the area which has easily caught scholarly attention is African indigenization theology, perhaps because African culture greatly suffered at the hands of foreign colonial conquerors and missionaries in their zeal to plant and spread the Christian faith. Consequently, there has developed a faulty theology of the church which has resulted in the lack of a sense of sociopolitical implications of the gospel in oppressive situations like in most African societies. But the aspect relatively unknown and very little written about until recently is African liberation theology. In recent times, however, the deteriorating human conditions in different parts of Africa and the unjust socio-political structures which sustain and promote these ills have necessitated a distinct theological inquiry and method to deal with them. The African theologians are now confronted with the problem of finding out whether the God of Moses who liberated the Israelites from Egyptian bondage and the God of Jesus of Nazareth who came to set the captives free created the blacks to remain in perpetual captivity and dehumanization.

When the Bible is read in the community of the poor, says Cone (1990), it is not understood by them as a deposit of doctrines or revealed truths about God. Rather it becomes a living book that tells the story of God's dealing with God's people. In what characteristics way can the African church participate fully in the people's struggle to extricate themselves from these social ills since the people's joy and hopes, grief and anguish remain those of the church in unity and solidarity with the oppressed and the marginalized, constitutes, therefore, the task of this paper. This is 
particularly so because just as any abstract and dispassionate discourse on the nature of God in relation to his dealing with his people would have made no impression on the Israelites in the days of their slavery in Egypt, so could Christian theologies not afford to ignore the reality of the suffering of African people today.

\section{Conceptual Clarifications}

Theology is always culture-bound. African Christian theology is one rooted, as it were, in African culture; that is to say, this theology arises in response to the problems inherent in, or peculiar to African culture. In short, African theology formally arose when it did out of the need to contextualize the received western theology and make it truly concrete, relevant, and functional to the African people. African theology has therefore its own tasks or modes of inquiry which, in fact, are different ways of reflecting on the African people's experiences and life situation in the light of the gospel.

African liberation theology, therefore, is one of these modes or main task of African theology as a distinct system. In deed this African liberation theology is known to have been borne out of the people's own experience of life situations as unjustly dominated (Politically) hence systematically exploited, racially oppressed, structurally poor, and in many cases, violently brutalized. Thus what spurred on this theology of liberation is to abolish the current unjust situation and to build a different society freer and more human. On the part of the African church herself, it certainly calls for her active commitment to the struggles of Africans for freedom, justice, and the humanization of the entire continent, what indeed the challenges of liberation theology in the context of African experience are all about. For as a critical reflection on the unjust African condition, African liberation theology calls particularly upon Christians to act, to live out their faith through action, to challenge the oppressive systems in which they found themselves and, above all, to help create a new social order, a new society, which is more equitable, more just, and which ultimately is for the good of all. Hence, African liberation theologians must toil for a theology for artisans of a new humanity in Africa. 
Nwadialor \& Nweke: The Relevance of the Church in Oppressive Situations...

It must, however, be noted that in this theology, the liberation in question is not simply a liberation from injustice, poverty, classism, racial oppression, and so on, but more importantly, a liberation to construct or build a more equitable humane society for all, which would mean particularly that the poor, the oppressed, would exercise mastery over their world and control their rhythm of progress. What constitutes, as it were, the very essence of liberation theology is this dialectical movement (Praxis) of a liberation from and liberation to, the one from structural injustice, the other, to construct or build a more equitable humane society for all. African liberation theology, therefore in a nutshell could be seen as a critical reflection on the experiences of the African people down through the ages and a total commitment to the process of development and the building of a new social order, all in the light of the gospel. It is not only a reflection on the experience of the people but also a commitment to practical process in the development and building of an equitable humane society using the Bible as a yardstick. Furthermore, the concept of liberation is a very dynamic one and it is manifest in times of desperate need. God is seen as almighty, all powerful and all saving for what he has done through Jesus Christ. Christ therefore delivers man from objective evil and revitalizes man in his weakness. Liberation here must be understood in its totality, as removal of all that which keeps the Africans in bondage, all that makes him less than what God intended him to be. It connotes the total idea of liberation from fear, uncertainty, sickness, evil powers, foreign domination and oppression, distortion of his humanity, poverty and want. In brief, it embraces religious, political, socio-economic, spiritual and mystical, personal and societal concern of the African people.

In the African context, and in the Bible, salvation as a theological concept cannot be complete without liberation as a socio-political concept. Jesus' own self-identification with the poor and needy makes his proclamation; I have come that they may have life and have it more abundantly-more meaningful to the African man. This ties in neatly with his traditional idea of religion, which strongly repudiates the complacent Euro-American doctrine of piein-the-sky-when-you die, which is a distortion of the message and 
passion of Christ. Tutu (1997) maintains that "only a spiritually, socially and economically free Africa, where Christianity today is expanding faster than anywhere else in the world, can make a distinctive contribution to the life of the body of Christ. In corroboration, Buthelezi (1997) maintains that "the traditional African would-view emphasized the wholeness of life; all life was sacramental and therefore was the meeting place of man and God" (p. 21). "The pivot, therefore, of the African liberation theology is found in the words of Jesus himself when he said-the spirit of the Lord is upon me because He has anointed me to announce good news to the poor, he has sent me to proclaim release for prisoners and recovery of sight for the blind, to let the broken victims go free, to proclaim the year of the Lord's favour (Luke 4: 18-19) (AppiahKubi, 1997). This takes us to the biblical justification of African liberation theology.

\section{Biblical background to African liberation theology}

It is pertinent to note here, especially at this time of acute social tensions, that the theology of liberation is rooted as it were, in the saving and liberating acts of God epitomized in the Exodus event, and which came to its culmination in the liberating acts of Jesus Christ. In the Exodus event God said to Moses that He has listened to the yearnings of his people, and he instructed Moses to go and ask Pharaoh to liberate the Israelites. It is important to note here that the liberation was both spiritual and temporal. The Israelites yearned for freedom to be able to worship their one and only God, Yahweh, uninterrupted and unhindered, and at the same time they needed political, economic and social liberation to be like other nations free from all forms of oppression, exploitations and man inhumanity to man that negated their aspirations for integral development both as individuals and as a nation. The Israelites did not only struggle for spiritual freedom that would enable them to be a worshipping group, ignoring the hard facts of their socio-political and economic realities that confronted them in Egypt. Rather their struggles were basically against the economic exploitation and general degradation that they were subjected to by the Pharaohs. 
Nwadialor \& Nweke: The Relevance of the Church in Oppressive Situations...

In the New Testament Christ is presented as man's supreme liberator. He came to save and liberate man from sin, the sources of his alienation from God and his fellow man. He sacrificed Himself to liberate man from any thing that oppresses him. This is a holistic liberation which concerns man in all the dimension of his being and existence. This liberation is therefore not only of the spiritual and interior but if has a direct impact on the concrete, individual and collective life of mankind. Christ cared for the need of man in their vertical and horizontal dimensions. Okolo (1985) points out that "He preached the good news, proclaimed release to the captives, gave sight to the blind and set the oppressed free" (p. 96). Christ's liberation acts in all their dimensions have remained the foundation doctrine of liberation theology. Nthamburi (1983) writes that "the gospel which Christ preached had a cutting edge because it was biased towards the poor, the oppressed, the prisoners, the outcast and the neglected" (p. 165). Thus, Christ's saving act, among others, provides the universal framework within which the liberation of man in his various categories of need takes place. It then means that there is no question of a dualistic conception of man's social realities. Consequently, the unjust societal structures and the social evils and problems which they breed should claim church's top attention.

Liberation theology observes that the biblical message of God's liberation has historical as well as eschatological dimensions. It does not only rest upon the historical event of the Exodus, but it also points to the future, the future of Yahweh which He has made also the future of His people (Boesak, 1997). This eschatological dimension should not lead to a theological paralysis, as has been the case in theology, a waiting patiently-upon-the-Lord kind of attitude. Nor must it lead to a theological escapism, an other-worldly religiousity which for so long has been a favourite way out for blacks. Liberation theology realizes that New Testament eschatology is a call to arms, a summons not to be content with the existing situation of oppression, but to take sides with the oppressed and the poor. This is to say that such an eschatological ethic would dissociate itself from an ethic of ordinances and would take on the character of an ethic of transformation. This transformation of the society can be called a revolution and this revolution need not 
necessary be violent. It is a fundamental social change; a movement from what is to what ought to be.

Oppression and exploitation of the less privilege in the society are nothing new. They existed before and in the time of Jesus, but he did not blow hot and cold about the matter. He took a clear and definite stand on the side of the less privileged and those who were marginalized by the society. Hence liberation theology insists that to be true to Christ, the church must opt for the poor. Liberation theology holds that the incarnation of Jesus makes it imperative for any Christian to accept his existence in this world as a reality which places on him the obligation to work for the transformation of the world. Hence Mayson (1985) says that "Christianity is about a liberation movement amongst us earthlings; being the story of Jesus of Nazareth who incarnated himself in man and his history, Christianity is intensely worldly and not particularly religious" (p. 13). There is no room for a flight from the world only to hope for eternal happiness in heaven because Christians do not lead a schizophrenic kind of life, with their feet on earth and their heads in heaven. Also Winter (1981) warns that,

To allow Christianity to degenerate into an instrument for the reform of the heart alone without doing anything about the state of the world that impoverish and dehumanize men is to give them an occasion to question the veracity and the relevance of the gospel message. (p. 36).

Maimeca (cited in Odey, 1996) further maintains that "it is impossible to be Christian without also committing oneself to the process of liberation" (p. 24). So the Christian message has to be placed in and evaluated on the basis of its practical application to the ethical, social, political and economic agenda left by Christ himself. From this perspective, liberation theology might be called faith in action. 
Nwadialor \& Nweke: The Relevance of the Church in Oppressive Situations...

\section{The African situation and the need for liberation theology}

It would be stating the obvious to note that the African situation is sufficiently due for liberation theology. It has been noted earlier that the peculiarity of the nature of human experience of injustice and social deprivation determines a particular theological task. It is for this that doing theology in African context calls for a theology of liberation because the Africans have experienced bitter conditions of poverty and un-freedom. Hence the Pan-African conference of The Third World Theologians, 1977 spoke for the necessity of African liberation theology when it declares that, we are committed to the struggles of our people to be free, and we believe that the theology that arises from that commitment will have three characteristics, one of which is liberation theology (Okolo, 1985).

An honest look at the African reality shows that the human situation is urgently yearning for a sincere theology of liberation. Various kinds of social injustice are very much operative at various levels, namely, political, economic, social even religious. The dialectics of the struggles between the rich and the poor, the haves and the have nots; the employed and the unemployed, the powerful and powerless, evident in Latin America for many years and which gave rise to her own brand of liberation theology has become a common place in Africa and has proved itself a great source of worry for the African masses. In effect, what this means is that in Africa many socio-political structures are sinful and unjust and these call for liberation and transformation. Consequently, Africa is ripe for a theology of liberation since injustices and other evils are incarnated in her socio-political structures. Again in Africa, as in many other developing nations, poverty has come to stern people in their faces; people increasingly aspire to freedom from poverty.

It is striking to note that poverty in Africa is largely manmade, and not as a result of bad luck or unalterable destiny. What is obvious in Africa is the existence and operation of unjust sociopolitical and hence power structures, built on networks of domination and exploitation of the poor by the rich and powerful, which are the causes of poverty. Consequently, sincere Christians in Africa must be committed to liberation which in turn must mean an 
unconditional option for and solidarity with the poor. It is for this that Sawyer (1997) maintains that,

The church in Africa is faced with a clamant demand for an interpretation of the Christian faith in a sanguine hope that such an interpretation, when produced, would provide a means of bringing home to Africans the truth of the Christian gospel in an idiom related to the African situation. (p. 10).

Poverty should indeed be a serious concern to the churches of the third world countries. Okolo (1985) opines that "it was not accidental that the association of Third World Theologians which met in New Delhi (India) in August 1981, emphasized poverty as an important social reality that ought to confront the theology of the third world" (p. 92). Our society has almost become one conscious of very wealthy, propertied elite. This class of elite, in conjunction with international capitalist forces channels the nation's wealth to themselves at the expense of the masses. These elite form part of the unjust society and become the exploiters of the people, benefiting from the suffering of countless others, and through their shady actions, such as bribery, embezzlement of public funds, illicit contract, questionable business deals, and so on, create a life if misery and economic hardship for the poor masses. It is a well known fact that African economic resources are in disarray and dormant, especially in the rural areas. Staggering and alarmingly increasing unemployment figures are the most banal features of our economy.

In our societies also, we have got nepotism, provincialism, ethnocentrism or tribalism, and various forms of institutionalized social discriminations. This sort of social atmosphere, deeply poisoned and violently charged as it is, poses a serious obstacle to justice and its administration and to the recognition and observance of human rights. Nthamburi (1983) expresses the effects of these social ills characteristic of Africa thus; "in addition to poor living conditions, other evils such as nepotism corruption, ethnicism, 
Nwadialor \& Nweke: The Relevance of the Church in Oppressive Situations...

racism, unemployment beset many communities and threaten their disintegration" (p.164).

In the area of politics, one of the important preoccupations of post independence Africa is the building up of or promoting a strong and dynamic African personality. The African wishes to be seen but above all, heard in the comity of nations. He wants to be free, without interference from the world super powers. Iwe (1985) maintains that to an international observer of the developing African socio-political setting, two striking features are in prominence. These are the issues or problems of industrial backwardness and the ugly and stubborn head of colonialism. It is for this that Okolo (1985) re-echoes Nkrumah's agitation in the following words" it is only in conditions of total freedom and independence from foreign rule and interference that the aspirations of our people will see real fulfillment and the African genius find its best expression" (p. 98). In short, independence from the white man has always meant for the African an unconditional thrust for self-reliance and self-projection through the various avenues of his culture as well as a serious struggle against those force, internal and external which reduces him to complete anonymity in world affairs.

In the domestic sphere, there is the glaring fact of irresponsible procreation or rather irresponsible conception which stubbornly perpetuates the reckless practice of launching new babies into the community, with or without the visibility of the means of livelihood. Iwe (1985) observes that "this typically Afro-Irish domestic malpractice had generally adamantly refused to yield to the principles and acceptable techniques of responsible and planned parenthood (p. 30). In consequence, definitely, recognizable human values are being jeopardized. It is human dignity and decency and security in the standard of living that are here being assailed, if not sacrifices. Often irresponsible reproduction gives rise to domestic classrooms of ape-looking children suffering from acute malnutrition and want of care.

It is also evident to all observes that illiteracy like malaria is a wide spread plague in Africa. Probably the greatest, obstacles to the realization of human person is ignorance and illiteracy which warp and surround with darkness the human personality, as they 
inhibit its growth and development. The good life, which is often acknowledged as the purpose of education becomes impossible where ignorance and illiteracy are the order of the day.

In the field of religion, it is a matter of common knowledge that religious ignorance and prejudice as well as unhealthy Christian rivalries and denominationalism abound in African communities. In the spheres of religion too, African personality, self-hood, independence has been a serious concern for the African church and its theologians who equally oppose the evils which endanger these values. The call for a missionary moratorium by the all African conference of churches (AACC) in 1974, was in defense of the selfhood, independence, autonomy of the African church and hence of the African person. According to Nthamburi (1983), "The call for a moratorium arose then, out of the desire of the African Christians to search for self-hood, self-expression, self determination and selfdevelopment" (pp. 168-169). Mbiti (1972) adds that as long as African Christians remain tied through this structural link to their counterparts over seas, they will not develop a proper image of themselves and contribute their parts to Christendom. "Africanization" is the basic concept used by African theologians to express this ardent need of the African church. It is African personality in action in the church, a proof that the church in this part of the world has come to age and should be respected as a selfindependent church; it is a struggle against running the church on the old colonial structures and pattern of the missionaries. It is indeed to see that the local church is not merely imitative of western modes, a mere transmitter of foreign customs and ideas.

Complete liberation or internal development becomes an important task for the African church. It would mean that for the church, Christianization is really inseparable from humanization (making the lives of people more human and the society more equitable). For the African man, these two inseparable tasks would mean that his struggle for the freedom of the children of God through baptism and other sacraments should really be inseparable from his foremost struggles against the problems and tensions of his social existence. Hence liberation as used here becomes an all- 
Nwadialor \& Nweke: The Relevance of the Church in Oppressive Situations...

inclusive concept applicable to the total man in his total environment; cutting across man's total needs body and soul.

\section{The implications of liberation theology and it's praxis to the African church}

The church in Africa is the church in midst of communities and peoples, Christians inclusive, struggling for liberation, emancipation, selfhood and control of their destiny. The church to be relevant to the people has to struggle side by side with them, sharing their joys, sorrows, anxieties and their daily burden. The hour of liberating struggle has struck for the African church. It has to engage itself also in the political, economic, social and cultural liberation of the people in transforming societal structures which breed humiliation, agony and death for a large section of African communities. To this, Nyerere (1997) opines that unless the church participates actively in the rebellion against those social structures and economic organizations which condemn men to poverty, humiliation and degradation, then the church will become irrelevant to man and the Christian religion will degenerate into a set of superstitions accepted by the fearful. Unless the church, its members and its organizations, expressed God's love for man by involvement and leadership in constructive protest against the present conditions of man, then it will die, and humanly speaking, deserves to die because it will then serve no purpose comprehensible to modern men.

The African church is to be fully sensitive to the needs and aspirations of the African man, it has to take his life situation seriously, understand him in his concrete needs and the sociopolitical factors which shaped and determined them. Okolo (1985) succinctly puts, "what is of utmost importance to the African church is the African person and problems he encounters in his life situation" (p. 90). There is the need to see the biblical material contextually. The lesson of the incarnation is the contextual nature of revelation. Hence Pobee (1984) maintains that "the Bible is redeeming the African individual from the power of superstition, individuality-crushing traditions, witchcraft and other forces that do no make for progress" (p. 8). The African church is therefore, required to make the effort to relate the words of scripture to the 

present day as part of the continuing encounter between God and His people, only then can the words of scripture have a transforming power today.

As a local church treading the path of liberation in the foot prints of Christ, man's liberator per excellence, the African church must develop a new sense of mission and responsibility towards the increasing poor and marginalized on the continent. The poor cannot rarely be helped by mere charity, what Friere (1973) would call false generosity as distinct from true generosity. The former ultimately begets more poverty, dependence, and powerlessness, were-as true generosity lies in striving so that these hands, whether of individuals or entire peoples need to be extended less and less in supplications, so that more and more they become human hands which work, and transform the world. The point of it all is that, a commitment to liberation theology and its development in African context must mean for the African church a new sense of awareness of the plight of the poor. In effect, what is required of the African church is action, not words, not platitudes or sterile condemnations of the rich and the powerful in society or empty denunciations of the societal ills in Africa. The church can run self-help programmes that could generate funds and employment for the masses, run orphanages for motherless and fatherless babies, and study various means to make money to help the poor help themselves. Definitely, the church can render much help by establishing some voluntary institutions such as domestic science centres, youth clubs, workers clubs, descent hotels and traveler's inn, low-price transport facilities, community water tanks, medical clinic, feeding centres, etc. Also in this economic sphere Iwe (1985) is of the opinion that Christian leaders can at least offer some solace and relief. They can summon the people to cooperative endeavours, aimed at pooling their resources to provide the necessary capital to improve their lot. The various Christian communities can help reduce unemployment by embarking on such projects as farm settlements, cottage industries and similar ventures. Such measures would convince the people that Christianity realistically appreciates those economic problems which inhibit the realization of personal fulfillment and the good life. 
Nwadialor \& Nweke: The Relevance of the Church in Oppressive Situations...

Again since one of the known social problems of African and other developing nations is overpopulation, particularly among the poor and uneducated. An important mission for the church in this regard is to help educate the masses on Planned Parenthood. Children are certainly gifts from God; however, a planned number of them are no less blessed. The African people must be told that the glory of God and of the church is children well fed, well clothed, well educated and not those battling with starvation, sickness and disease.

Christianity can certainly demolish the religious fear and phobia and ignorance at the basis of this practice of ill-planned and irresponsible parenthood. Here it has a mission of enlightenment and truthfulness, courage and sympathy to accomplish in the interest of human dignity and decency. More so, Christianity has got to exercise its mission of enlightenment and cultivation of intellectual values. It should come to the help of the African nations in their effort to create a sound and viable educational system for the people. Christianity possesses unquestionable intellectual and educational resources. These it can place at the disposal of the emergent governments of developing Africa. Iwe (1985) is of the opinion that there is an urgent need in new Africa to evolve a participatory system of education under the supervisory and financial control of the state. This system, he maintained has the unrivalled merit of mobilizing all the available resources-material and human, moral and spiritual, voluntary, communal and state owned -and harnessing them to human advancement and national prosperity.

The church also has a positive role to play in the political and personality development in the context of African societies. Although the church in the pre-independent period became linked with the colonial structure, the church now can involve itself in all aspects of people's struggle for political liberation. The moral conscience of humanity could be aroused by Christianity to action against the dangers posed by colonialism and industrial backwardness to such values as liberty, national self-determination and modernity and decency in the standard of living. The moral indefensibility of this later $21^{\text {st }}$ century colonial maneuvering in Africa, the human responsibilities of the affluent nations towards the 
developing regions and the propriety of support for freedom fights are ideas and messages which Christian authorities and leaders may do well to propagate. Finally, African theologians should work towards the development of African Christianity that will recognize distinct African personality and culture as positive contributions to the universal church.

Indeed, the full maturity of the church in Africa in the $21^{\text {st }}$ century would mean to act as Jesus did, feed the hungry, give drink to the thirsty, and set the oppressed free, and so on. This is what commitment to African liberation theology essentially demands.

\section{Conclusion}

Liberation theology is the product of awareness that oppression and exploitation of the less privileged people are man-made, sinful, and therefore contradicts everything the gospel message stands for. Therefore, anything which claims to be good news for all but fails to address itself squarely to those conditions cannot be taken seriously by the oppressed. Until the good news takes a concrete form and fight against all forms of impoverishment and exploitation as going against God's will, the reign of God which is the reign of justice, will never be ushered in, and as long as the reign of justice is deferred, the poor, who are always the helpless victims of injustice, will continue to question the authenticity and relevance of the good news. Hence Odey (1996) notes that,

Any theologian worth the name is thus challenged to make an option for the poor with the view to liberating them from the unjust structures that shackles them. Such an option becomes an imperative for the theologian because it is God's own option. (p. 12).

This is particularly so because Christianity in its various institutional and social forms and manifestations is a human and moral, spiritual and cultural, national and international force to be reckoned with. As a religion its claims are both human and divine. Its incarnate nature and foundations give it an inescapable and essential human 
Nwadialor \& Nweke: The Relevance of the Church in Oppressive Situations...

dimension. The special contention here is that the resources of Christianity require immediate mobilization and effective deployment here in our developing African region where human and non human factors has joined forces to dehumanize the human person and denied him of the freedom-body and soul-implicit in the relationship between God and man which culminated in the salvific work of Christ.

A church that here hold up to us the prospects of a heavenly bliss must inspire us here below with faith and hope, and the earthly foretaste of that heavenly glory. The Christian church that proclaims the message of Christ must not forget that the same Lord Jesus was at the wedding feast of Cana, that He multiplied loaves and converted water into wine to relieve physical want, that He removed physical disabilities and deformities, and finally that He cherished, not only the interior nature of religion but also the cosmetic box and make-up of Mary Magdalene (Iwe, 1985). The Christian church that preaches faith in resurrection of the dead must also recognize that there is going to be no resurrection without the concurrent resurrection of the body.

* Kanayo Louis Nwadialor is a lecturer in the Department of Religion and Human Relations, Nnamdi Azikiwe University, Awka. nwadialorkanayo@yahoo.com

* Charles Chukwuemeka Nweke is a lecturer in the Department of Philosophy, Nnamdi Azikiwe University, Awka. nkesun2002@yahoo.com 


\section{References}

Appiah-Kubi, K. (1997). Christology. In J. Parratt (Ed.). A reader in African theology (pp. 65-74). London: SPCK.

Barrett, D.B. (1970). Schism \& renewal in Africa: An analysis of six thousand contemporary religious movements. London: Oxford University.

Boesack, A. (1997). An ethic of liberation for South Africa. In J. Parratt (Ed.). A reader in African theology (pp. 120-128). London: SPCK.

Buthelezi, M. (1997). Salvation as wholeness. In J. Parratt (Ed.). A reader in African theology (pp. 85-90). London: SPCK.

Cone, J.H. (1990). A black theology of liberation. New York: Orbis. Friere, J. (1973). Pedagogy of the oppressed. New York: The seabury.

Iwe, N.S.S. (1985). Christianity and culture in Africa: Owerri University.

Mayson, C.A. (1985). A certain sound: The struggle for liberation in South Africa. New York: Orbis.

Mbiti, J. (1972). The crisis of mission in Africa. African Journal of Theology, 5.

Nthamburi, Z. (1983). Making the gospel relevant within the African context and culture, $A F E B, 25,3$.

Nyerere, J. (1997). The church's role in society. In J. Parratt (Ed.). A reader in African theology (pp. 109-119). London: SPCK.

Odey, J.O. (1996). Africa, the agony of a continent can liberation theology offer any solution? Enugu: Snaap.

Okolo, C.B. (1985). The Igbo church and liberation motive. In C.B. Okolo (Ed.). The Igbo church and the quest for God (pp. 89113). Obosi: Pacific College.

Pobee, J.S. (1984). Bible and human transformation. Journal of The International Association for Mission Studies, 1, 2, 4-12.

Sawyer, H. (1997). What is African theology? In J. Parratt (Ed.). A reader in African theology (pp. 9-22). London: SPCK.

Tutu, D.M. (1997). Black theology and African theology: Soul mates or antagonists? In J. Parratt (Ed.). A reader in African theology (pp. 36-44). London: SPCK.

Winter, C. (1981). The breaking process. London: SCM. 